\title{
EKSPERIMENTASI PENGGUNAAN MEDIA KOMPUTER DALAM PEMBELAJARAN MATEMATIKA PADA POKOK BAHASAN LOGARITMA DITINJAU DARI MOTIVASI BELAJAR SISWA KELAS X SMA KOTA SURAKARTA
}

\begin{abstract}
Arif Ganda Nugroho
Abstrak

Kemajuan teknologi telah membawa perubahan pesat dalam peradaban manusia. Komputer adalah salah satu bentuk dari kemajuan di bidang ilmu pengetahuan dan teknologi. Dalam sektor pendidikan, pemanfaatan komputer sudah berkembang sebagai alternatif dalam pemilihan media pembelajaran. Salah satunya adalah pemanfaatan software macromedia flash 8 di dalam pembelajaran Matematika. Tujuan penelitian ini adalah untuk mengetahui: (1) apakah pembelajaran matematika dengan media pembelajaran macromedia flash 8 menghasilkan prestasi belajar matematika yang lebih baik daripada pembelajaran dengan media powerpoint, (2) apakah motivasi belajar tinggi akan memberikan prestasi belajar matematika yang lebih baik dibandingkan dengan motivasi belajar sedang, motivasi belajar sedang lebih baik daripada motivasi belajar rendah dan motivasi belajar tinggi lebih baik daripada motivasi belajar rendah. (3) apakah ada interaksi antara media pembelajaran dengan motivasi belajar terhadap prestasi belajar. Penelitian ini merupakan penelitian eksperimen semu. Populasi dalam penelitian ini adalah seluruh siswa kelas $X$ SMA SSN Kota Surakarta. Pengambilan sampel dilakukan dengan stratified cluster random sampling. Metode pengumpulan data adalah metode dokumentasi, angket, dan tes. Instrumen penelitian adalah tes prestasi belajar matematika sejumlah 25 butir soal dan angket motivasi belajar siswa sejumlah 40 butir soal.
\end{abstract}

Kata Kunci: pembelajaran, macromedia flash 8, powerpoint, motivasi, prestasi belajar

\section{Pendahuluan}

Pendidikan mempunyai tujuan yang sangat penting untuk menjamin perkembangan dan kelangsungan bangsa. Menurut UndangUndang Republik Indonesia Nomor 20 Tahun 2003 tentang Sistem 
Arif Ganda Nugroho

Pendidikan Nasional disebutkan bahwa pendidikan adalah usaha sadar dan terencana untuk mewujudkan suasana belajar dan proses pembelajaran agar peserta didik secara aktif mengembangkan potensi dirinya untuk memiliki kekuatan spiritual keagamaan, pengendalian diri, kepribadian, kecerdasan, akhlak mulia, serta keterampilan yang diperlukan dirinya, masyarakat, bangsa dan negara. Dengan landasan pemikiran tersebut, pendidikan nasional disusun sebagai usaha untuk memungkinkan bangsa Indonesia mempertahankan kelangsungan hidupnya dan mengembangkan diri secara terus-menerus dari satu generasi ke generasi berikutnya. Pendidikan harus dipersiapkan sedemikian rupa sehingga mampu menjawab segala kebutuhan permasalahan dan tantangan hidup.

Kemajuan teknologi telah membawa perubahan pesat dalam peradapan manusia. Pekerjaan yang dilakukan manusia secara manual kini dapat digantikan dengan mesin. Hal tersebut menuntut manusia untuk berpikir lebih maju dalam segala hal agar tidak dianggap tertinggal. Komputer sebagai salah satu bentuk dari kemajuan di bidang ilmu pengetahuan dan teknologi dapat dimanfaatkan oleh manusia sebagai teknologi informasi dan komunikasi sehingga dapat mendorong manusia untuk lebih meningkatkan efisiensi dan efektivitasnya.

Dalam meningkatkan mutu pendidikan khususnya pembelajaran matematika, perlu ditunjang adanya pembaharuan di bidang pendidikan. Kualitas pembelajaran matematika dapat dilihat dari prestasi belajar matematika siswa. Banyak faktor yang mempengaruhi prestasi belajar matematika. Faktor-faktor yang mempengaruhi keberhasilan dalam belajar yaitu faktor internal dan faktor eksternal. Faktor internal adalah faktor yang berasal dari dalam diri siswa, di antaranya yaitu motivasi belajar, kecerdasan, minat belajar, kedisiplinan siswa, kemandirian belajar, aktivitas belajar siswa, dan sebagainya. Faktor eksternal adalah faktor yang berasal dari luar diri siswa, antara lain meliputi metode mengajar, media pembelajaran yang digunakan dalam mengajar, lingkungan sosial, fasilitas belajar dan lingkungan keluarga. 
Eksperimentasi Penggunaan Media Komputer dalam Pembelajaran Matematika pada Pokok Bahasan Logaritma Ditinjau dari Motivasi Belajar Siswa Kelas X Sma Kota Surakarta

Dalam sektor pendidikan, pemanfaatan komputer sudah berkembang tidak hanya sebagai alat yang hanya dipergunakan untuk membantu urusan keadministrasian saja, melainkan juga sangat dimungkinkan untuk digunakan sebagai salah satu alternatif dalam pemilihan media pembelajaran. Sebagai contoh, dengan adanya komputer multimedia yang mampu menampilkan gambar maupun tulisan yang diam dan bergerak serta bersuara, sudah saatnya komputer dijadikan sebagai salah satu alternatif pilihan media pembelajaran yang efektif dan menarik. Hal semacam ini perlu ditanggapi secara positif oleh para guru, khususnya guru bidang studi matematika, sehingga komputer dapat menjadi salah satu alternatif media yang dapat digunakan dalam proses pembelajaran yang pada akhirnya diharapkan dapat meningkatkan kualitas hasil belajar para siswa.

Rendahnya prestasi belajar matematika juga dipengaruhi oleh motivasi belajar siswa dan media pembelajaran yang digunakan. Motivasi belajar siswa terhadap matematika cukup memegang peranan yang besar dalam menentukan hasil prestasi belajar matematika.

Matematika merupakan pelajaran yang bersifat abstrak, sehingga dituntut kemampuan guru untuk dapat mengupayakan media pembelajaran yang tepat sesuai dengan tingkat perkembangan mental siswa. Banyak sekali guru matematika yang menggunakan waktu pelajaran dengan kegiatan membahas tugas-tugas lalu memberi pelajaran baru, dan memberi tugas pada siswa. Pembelajaran di atas rutin dilakukan hampir tiap hari sehingga dapat dikategorikan sebagai $3 \mathrm{~m}$, yaitu membosankan, membahayakan, dan merusak seluruh motivasi belajar siswa. Sebagai akibatnya, siswa kurang termotivasi untuk menyelesaikan masalah dalam kehidupan sehari-hari yang berkaitan dengan pelajaran matematika.

Belajar matematika adalah proses dimana matematika ditemukan dan dibangun manusia, sehingga dalam pembelajaran, matematika harus 
Arif Ganda Nugroho

lebih dibangun oleh siswa dari pada ditanamkan oleh guru. Untuk mengantisipasi masalah tersebut maka perlu dicarikan formula pembelajaran yang tepat, sehingga dapat meningkatkan motivasi belajar pada siswa khususnya pada pokok bahasan logaritma dalam pembelajaran matematika. Para guru terus berusaha menyusun dan menerapkan berbagai metode yang bervariasi agar siswa tertarik dan bersemangat dalam belajar matematika. Salah satunya dengan menggunakan media pembelajaran yaitu macromedia flash 8.

Menurut Sudjana dan Rivai (2001:2-3), media pembelajaran dapat mempertinggi proses belajar siswa dalam pembelajaran yang pada gilirannya diharapkan dapat mempertinggi hasil belajar yang dicapainya. Ada beberapa alasan, mengapa media pembelajaran dapat mempertinggi proses belajar siswa. Alasan pertama berkenaan dengan manfaat media pembelajaran dalam proses belajar siswa, antara lain: (a) Pembelajaran akan lebih menarik perhatian siswa sehingga dapat menumbuhkan motivasi belajar, (b) Bahan pembelajaran akan lebih jelas maknanya sehingga akan lebih dipahami oleh siswa dan memungkinkan mereka menguasai tujuan pembelajaran dengan lebih baik, (c) Metode mengajar akan lebih bervariasi, tidak semata-mata komunikasi verbal melalui penuturan katakata oleh guru, sehingga siswa tidak bosan dan guru tidak kehabisan tenaga, apalagi bila guru mengajar untuk setiap jam pelajaran, (d) Siswa lebih banyak melakukan kegiatan belajar sebab tidak hanya mendengarkan uraian guru, tetapi juga aktivitas lain seperti mengamati, melakukan, mendemonstrasikan, dan lain-lain. Alasan kedua mengapa penggunaan media pembelajaran dapat mempertinggi proses dan hasil pembelajaran adalah berkenaan dengan taraf berpikir siswa. Taraf berpikir manusia mengikuti tahap perkembangan dimulai dari berpikir konkret menuju ke berpikir abstrak, dimulai dari berpikir sederhana menuju berpikir kompleks. Penggunaan media pembelajaran erat kaitannya dengan tahapan berpikir tersebut sebab melalui media pembelajaran hal-hal yang abstrak dapat dikonkretkan, dan hal-hal yang kompleks dapat disederhanakan. 
Eksperimentasi Penggunaan Media Komputer dalam Pembelajaran Matematika pada Pokok Bahasan Logaritma Ditinjau dari Motivasi Belajar Siswa Kelas X Sma Kota Surakarta

Berdasarkan uraian di atas maka penulis mencoba meneliti penggunaan media pembelajaran dengan memanfaatkan software macromedia flash 8 serta apakah ada perbedaan prestasi belajar matematika antara kelas yang diajarkan dengan menggunakan macromedia flash 8 dan kelas yang diajarkan dengan powerpoint ditinjau dari motivasi belajar siswa.

\section{Metode Penelitian}

Jenis penelitian yang dilakukan merupakan penelitian eksperimen semu. Menurut Budiyono (2003: 82-83), tujuan penelitian eksperimen semu adalah untuk memperoleh informasi yang merupakan perkiraan informasi yang dapat diperoleh dengan eksperimen yang sebenarnya dalam keadaan yang tidak memungkinkan untuk mengontrol dan atau memanipulasi semua variabel yang relevan. Penelitian ini bermaksud memberikan perlakuan terhadap sampel yang diambil dari populasi, selanjutnya peneliti ingin mengetahui efek perlakuan tersebut. Perlakuan yang dimaksud adalah pada kelompok eksperimen 1 dikenai perlakuan pembelajaran yang menggunakan media pembelajaran dengan software macromedia flash 8 , sedangkan pada kelompok eksperimen 2 dikenai dengan perlakuan pengajaran menggunakan media pembelajaran software powerpoint, untuk selanjutnya dilihat pengaruhnya terhadap variabel lain yaitu prestasi belajar.

Penelitian ini hanya akan meneliti dua variabel bebas yang dianggap telah mewakili untuk melihat pengaruhnya terhadap satu variabel terikat, baik pengaruh parsial kedua variabel bebas tersebut terhadap satu variabel terikat, maupun pengaruh kedua variabel bebas secara bersamasama terhadap variabel terikat. Kedua variabel bebas (independent variabel) tersebut adalah media pembelajaran (X1) dan motivasi belajar siswa (X2), sedangkan variabel terikat (dependent variable) adalah prestasi 
Arif Ganda Nugroho

belajar siswa (Y). Kedua variabel tersebut dijadikan objek penelitian, sedangkan subjek penelitiannya adalah siswa kelas X SMA SSN Kota Surakarta pada tahun pelajaran 2010/2011.

Menurut Suharsimi Arikunto (2006: 130), "populasi adalah keseluruhan subjek penelitian" Sedangkan menurut Budiyono (2000: 119) populasi adalah keseluruhan pengamatan yang ingin diteliti berhingga atau tidak berhingga. Dalam penelitian ini populasinya adalah seluruh siswa kelas $X$ dari 20 SMA SSN Kota Surakarta. Sampel adalah kelompok kecil yang secara nyata diteliti dan ditarik kesimpulan dari padanya (Sukmadinata, 2007: 250). Sampel dalam penelitian ini adalah siswa kelas X SMA Negeri 2 Surakarta, SMA Batik 2 Surakarta, dan SMA Muhammadiyah 2 Surakarta. Pengambilan sampel dilakukan dengan cara stratified cluster random sampling. Tahapan yang dilakukan dalam pengambilan sampel yaitu dari seluruh SMA SSN yang ada di Kota Surakarta, yaitu 20 SMA, terlebih dahulu dikelompokkan menjadi tingkatan tinggi, sedang, dan rendah. Pengelompokkan tersebut berdasarkan nilai rata-rata hasil ujian akhir nasional tahun 2009/2010.

Teknik pengumpulan data yang digunakan dalam penelitian ini menggunakan dua metode, yaitu:

1. Metode pokok yang digunakan adalah (a) metode tes yaitu serentetan pertanyaan atau latihan serta alat lain yang digunakan untuk mengukur keterampilan, pengetahuan intelegensi, kemampuan atau bakat yang dimiliki oleh individu atau kelompok. Sebelum digunakan untuk menguji subjek penelitian, tes tersebut telah diujicobakan pada siswa kelas X.1 dan X.2 SMA Negeri 7 Surakarta dan (b) metode angket adalah sejumlah pertanyaan tertulis yang digunakan untuk memperoleh informasi dari responden dalam arti laporan tentang pribadinya, atau hal-hal yang ia ketahui (Suharsimi Arikunto, 2006: 151). Metode angket menggunakan skala Likert dengan kisaran 1-5 sebagai alternatif jawaban.

2. Metode bantu yang digunakan adalah (a) metode observasi atau pengamatan, yaitu suatu teknik atau cara mengumpulkan data dengan 
Eksperimentasi Penggunaan Media Komputer dalam Pembelajaran Matematika pada Pokok Bahasan Logaritma Ditinjau dari Motivasi Belajar Siswa Kelas X Sma Kota Surakarta

jalan mengadakan pengamatan terhadap kegiatan yang sedang berlangsung (Sukmadinata, 2007: 220). Metode observasi yang dilakukan peneliti adalah dengan mendatangi langsung sekolah yang akan dijadikan sampel penelitian. (b) metode dokumentasi yang digunakan dalam penelitian ini adalah data nilai UAN matematika siswa kelas X tahun pelajaran 2009/2010 yang selanjutnya digunakan untuk uji keseimbangan kemampuan awal antara kelas eksperimen 1 dengan kelas eksperimen 2.

Sebelum dikenakan pada sampel penelitian, instrumen yang telah disusun, diujicobakan terlebih dahulu. Uji coba ini dimaksudkan untuk mengetahui apakah instrumen tes yang telah disusun memenuhi syaratsyarat instrumen yang baik. Syarat-syarat tersebut antara lain sebagai berikut:

\section{Validitas Instrumen}

Validitas yang digunakan adalah validitas isi. Menurut Budiyono (2003: 58), suatu instrumen valid menurut validitas isi apabila isi instrumen tersebut telah merupakan sampel yang representatif dari keseluruhan isi hal yang akan diukur.

Untuk menilai apakah suatu instrumen mempunyai validitas isi yang tinggi atau tidak, yang biasanya dilakukan adalah melalui experts judgment (penelitian yang dilakukan oleh para pakar) dan semua kriteria penelaahan soal tes harus disetujui semua oleh validator. Dalam hal ini, para pakar menilai apakah kisi-kisi tes dan angket yang dibuat sudah menunjukkan bahwa klasifikasi kisi-kisi telah mewakili isi yang akan diukur. Langkah selanjutnya, para penilai menilai apakah masingmasing butir tes dan angket yang telah disusun cocok atau relevan dengan klasifikasi kisi-kisi yang ditentukan.

2. Reliabilitas Instrumen 
Arif Ganda Nugroho

Menurut Budiyono (2003: 65), "suatu instrumen dikatakan reliabel apabila hasil pengukuran dengan instrumen tersebut adalah sama jika pengukuran tersebut dilakukan pada orang yang sama pada waktu yang berlainan atau pada orang yang berlainan (tetapi mempunyai kondisi yang sama) pada waktu yang sama atau pada waktu yang berlainan”. Dalam penelitian ini, tes prestasi belajar yang penulis gunakan adalah tes objektif, dengan setiap jawaban benar diberi skor 1, dan setiap jawaban salah atau tidak menjawab diberi skor 0 . sehingga untuk menghitung tingkat reliabilitas tes ini digunakan rumus Kuder- Richardson dengan KR-20.

Suatu instrumen dianggap baik atau dapat digunakan dalam kaitannya dengan uji reliabilitas jika indeks reliabilitasnya lebih dari 0,70 atau $r_{11} \geq 0,70$.

\section{Teknik Analisis Data}

\section{Uji Prasyarat Analisis dan Uji Keseimbangan}

Uji keseimbangan dilakukan untuk mengetahui apakah kelompok eksperimen 1 dan kelompok eksperimen 2 dalam keadaan seimbang atau tidak sebelum mendapat perlakuan. Dengan kata lain, secara statistik uji ini dilakukan untuk mengetahui apakah terdapat perbedaan mean yang berarti dari dua sampel yang independen. Sebelum dilakukan uji keseimbangan maka perlu dilakukan uji prasyarat untuk uji keseimbangan yaitu uji normalitas dan uji homogenitas.

\section{a. Uji Normalitas}

Uji normalitas digunakan untuk mengetahui apakah sampel berasal dari populasi yang berdistribusi normal atau tidak. Uji normalitas yang digunakan adalah metode Lilliefors. Langkahlangkah metode Lilliefors adalah sebagai berikut:

1) Hipotesis

$\mathrm{H}_{0}$ : Sampel berasal dari populasi berdistribusi normal

$\mathrm{H}_{1}$ : Sampel tidak berasal dari populasi berdistribusi normal

2) Statistik Uji 
Eksperimentasi Penggunaan Media Komputer dalam Pembelajaran Matematika pada Pokok Bahasan Logaritma Ditinjau dari Motivasi Belajar Siswa Kelas X Sma Kota Surakarta

$\mathrm{L}=$ Maks $\left|\mathrm{F}\left(z_{i}\right)-\mathrm{S}\left(z_{i}\right)\right|$

dengan:

$\mathrm{F}\left(z_{i}\right)=\mathrm{P}\left(\mathrm{Z} \leq \mathrm{z}_{\mathrm{i}}\right)$ dengan $\mathrm{Z} \sim \mathrm{N}(0,1)$

$\mathrm{S}\left(z_{i}\right)=$ Proporsi cacah $\mathrm{Z} \leq \mathrm{z}_{\mathrm{i}}$ terhadap seluruh cacah $z_{i}$

$s=$ deviasi standar atau simpangan baku

$\mathrm{z}_{i}=$ skor standar dengan $\mathrm{z}_{i}=\frac{\left(\mathrm{X}_{\mathrm{i}}-\bar{X}\right)}{\mathrm{s}}$

3) Taraf Signifikansi $\alpha=0,05$

4) Daerah Kritik

$D K=\left\{\boldsymbol{L} \mid \boldsymbol{L}>\boldsymbol{L}_{\alpha ; n}\right\}$ dibandingkan dengan $\mathrm{L}_{\text {tabel. }}$.

Harga $\mathrm{L}_{\alpha, \mathrm{n}}$ dapat diperoleh dari tabel Lilliefors pada tingkat signifikansi $\alpha$ dengan derajat kebebasan n.

5) Keputusan Uji

$\mathrm{H}_{0}$ ditolak jika $\mathrm{L} \in \mathrm{DK}$, atau $\mathrm{H}_{0}$ diterima jika $\mathrm{L} \notin \mathrm{DK}$

6) Kesimpulan

- Sampel berasal dari populasi yang berdistribusi normal jika $\mathrm{H}_{0}$ diterima.

- Sampel tidak berasal dari populasi yang berdistribusi normal jika $\mathrm{H}_{0}$ ditolak.

(Budiyono, 2009: 170 - 171).

\section{b. Uji Homogenitas}

Uji homogenitas bertujuan untuk menguji apakah sampel berasal dari populasi yang homogen atau tidak. Metode yang digunakan adalah dengan uji Bartlett. Prosedur pemakaiannya adalah sebagai berikut:

1) Hipotesis

$$
\mathrm{H}_{0}: \sigma_{1}^{2}=\sigma_{2}^{2}=\ldots=\sigma_{k}^{2} \text { (variansi homogen) }
$$


Arif Ganda Nugroho

$\mathrm{H}_{1}$ : paling sedikit satu variansi yang berbeda (populasi tidak homogen)

2) Statistik Uji

$\chi^{2}=\frac{2,303}{c}\left(f \log R K G-\sum f_{j} \log S_{j}^{2}\right)$

dengan:

$\chi^{2}$ berdistribusi $\chi_{(k-1)}^{2}$

$\mathrm{k}=$ Banyak seluruh nilai

$\mathrm{f}=$ Derajat kebebasan untuk RKG $=\mathrm{N}-\mathrm{k}$

$f_{j}=$ Derajat kebebasan untuk $S_{j}^{2}=\mathbf{n}_{j}-\mathbf{1}$

$\mathrm{j} \quad=1,2, \ldots, \mathrm{k}$

$\mathrm{N}=$ Banyaknya seluruh nilai (ukuran)

$\mathrm{n}_{\mathrm{j}}=$ Banyaknya nilai (ukuran) sampel ke-j = ukuran sampel ke-j

$c=1+\frac{1}{3(k-1)}\left(\sum \frac{1}{f_{j}}-\frac{1}{f}\right)$

$\mathrm{RKG}=\frac{\sum \mathrm{SS}_{\mathrm{j}}}{\sum \mathrm{f}_{\mathrm{j}}} ; \mathrm{SS}_{\mathrm{j}}=\sum \mathrm{X}_{\mathrm{j}}^{2}-\frac{\left(\sum \mathrm{X}_{\mathrm{j}}\right)^{2}}{\mathrm{n}_{\mathrm{j}}}=\left(n_{\mathrm{j}}-1\right) \mathrm{s}_{\mathrm{j}}^{2}$

3) Taraf Signifikansi $\alpha=0,05$

4) Daerah Kritik

$\mathrm{DK}=\left\{\chi^{2} \mid \chi^{2}>\chi_{\alpha ; k-1}^{2}\right\}$

5) Keputusan Uji

$\mathrm{H}_{0}$ di tolak jika $\chi^{2} \in \mathrm{DK}$ atau $\mathrm{H}_{0}$ diterima jika $\chi^{2} \notin \mathrm{DK}$

6) Kesimpulan

- Populasi dikatakan homogen jika $\mathrm{H}_{0}$ diterima.

- Populasi dikatakan tidak homogen jika $\mathrm{H}_{0}$ ditolak.

(Budiyono, 2009: 174 -

\section{c. Uji Keseimbangan}


Eksperimentasi Penggunaan Media Komputer dalam Pembelajaran Matematika pada Pokok Bahasan Logaritma Ditinjau dari Motivasi Belajar Siswa Kelas X Sma Kota Surakarta

Setelah prasyarat uji t terpenuhi selanjutnya dilakukan uji keseimbangan dengan statistik uji yang digunakan uji t. Data yang akan diuji berupa data nilai Ujian Akhir Nasioanal Kelas IX SMP untuk bidang studi Matematika. Langkah-langkah uji keseimbangan adalah sebagai berikut:

1) Hipotesis

$\mathrm{H}_{0}: \mu_{1}=\mu_{2}$ (kedua kelompok memiliki kemampuan awal yang sama)

$\mathrm{H}_{1}: \mu_{1} \neq \mu_{2}$ (kedua kelompok memiliki kemampuan awal berbeda)

2) Statistik Uji

$$
\begin{aligned}
& t=\frac{\bar{X}_{1}-\bar{X}_{2}-d_{0}}{s_{p} \sqrt{\frac{1}{n_{1}}+\frac{1}{n_{2}}}} \quad \sim \quad t\left(n_{1}+n_{2}-2\right) \quad \text { dengan } \\
& s_{p}^{2}=\frac{\left(n_{1}-1\right) s_{1}^{2}+\left(n_{2}-1\right) s_{2}^{2}}{n_{1}+n_{2}-2} \\
& \text { dengan: } \\
& \bar{X}_{1}=\text { rata-rata nilai tes kemampuan awal siswa pada kelompok } \\
& \text { eksperimen } 1 \\
& \bar{X}_{2}=\text { rata- rata nilai tes kemampuan awal siswa pada kelompok } \\
& \text { eksperimen } 2 \\
& s_{1} \quad=\text { simpangan baku kelompok eksperimen } 1 \\
& s_{2} \quad=\text { simpangan baku kelompok eksperimen } 2 \\
& n_{1} \quad \text { = banyaknya siswa kelompok eksperimen } 1 \\
& n_{2} \quad \text { = banyaknya siswa kelompok eksperimen } 2 \\
& \mathrm{~S}_{\mathrm{P}}^{2}=\text { variansi gabungan kelompok eksperimen1 dan } \\
& \text { eksperimen2 } \\
& \mathrm{d}_{0}=0 \text { (sebab tidak dibicarakan selisih rerata) }
\end{aligned}
$$


Arif Ganda Nugroho

3) Taraf Signifikansi $\alpha=0,05$

4) Daerah Kritik

$\mathrm{DK}=\left\{t \mid \mathrm{t}<-\mathrm{t}_{\frac{\alpha}{2} ; \mathrm{n}_{1}+\mathrm{n}_{2}-2}\right.$ atau $\left.\mathrm{t}>\mathrm{t}_{\frac{\alpha}{2} ; \mathrm{n}_{1}+\mathrm{n}_{2}-2}\right\}$

5) Keputusan Uji

$\mathrm{H}_{0}$ ditolak jika $t$ terletak di daerah kritik ( $t \in \mathrm{DK}$ )

6) Kesimpulan

- Kedua kelompok memiliki kemampuan awal sama jika $H_{0}$ diterima.

- Kedua kelompok memiliki kemampuan awal berbeda jika $\mathrm{H}_{0}$ ditolak.

(Budiyono, 2009: 151)

\section{Hasil dan Pembahasan}

\section{Hipotesis Pertama}

Pada hipotesis pertama, prestasi belajar matematika siswa dilihat dari penggunaan media pembelajaran. Berdasarkan uji anava dua jalan sel tak sama yang telah dilakukan, diperoleh $\mathrm{F}_{\mathrm{a}}=6,245$ dengan $\mathrm{F}_{\text {tabel }}=$ 3,840. Dengan demikian $F_{a}>F_{\text {tabel }}$, sehingga dapat disimpulkan bahwa $\mathrm{H}_{\mathrm{OA}}$ ditolak. Hal ini berarti bahwa terdapat perbedaan prestasi belajar antara penggunaan media pembelajaran dengan macromedia flash 8 dan penggunaan media pembelajaran dengan powerpoint.

Berdasarkan uji lanjut pasca anava dengan membandingkan rataan marginal pada siswa yang diberi perlakuan dengan media pembelajaran macromedia flash 8 yaitu 77,77 dan rataan marginal pada siswa yang diberi perlakuan dengan media pembelajaran powerpoint yaitu 74,52, diperoleh kesimpulan bahwa prestasi belajar siswa yang menggunakan media pembelajaran macromedia flash 8 memiliki prestasi yang lebih baik jika dibandingkan dengan prestasi belajar siswa yang menggunakan media pembelajaran powerpoint. 
Eksperimentasi Penggunaan Media Komputer dalam Pembelajaran Matematika pada Pokok Bahasan Logaritma Ditinjau dari Motivasi Belajar Siswa Kelas X Sma Kota Surakarta

Dengan demikian dalam proses pembelajaran dengan menggunakan media pembelajaran macromedia flash 8 dapat dengan mudah membangkitkan motivasi belajar siswa dan merangsang siswa untuk aktif dalam proses pembelajaran dan tidak memperkecil arti pokok pembelajarannya, tetapi justu membantu memperjelasnya. Media pembelajaran macromedia flash 8 dapat menggambarkan secara nyata contoh penerapan matematika dalam kehidupan sehari-hari.

Faktor lain yang dapat mempengaruhi prestasi belajar adalah adanya peranan guru dan motivasi siswa dalam proses belajar mengajar, sarana dan prasarana yang digunakan dalam proses belajar mengajar kaitannya dengan penggunaan media pembelajaran macromedia flash 8 , serta lingkungan sekolah yang mendukung.

Adapun peranan guru dalam proses belajar mengajar meliputi: ketepatan waktu dalam masuk kelas dan penggunaan media pembelajaran yang sesuai sehingga siswa lebih mudah memahami materi yang diajarkan.

Beberapa guru yang sudah menggunakan media pembelajaran macromedia flash 8 mengatakan bahwa mengajar siswa dengan menggunakan macromedia flash 8 lebih baik dan mudah menarik perhatian siswa sehingga siswa termotivasi untuk aktif dalam belajar matematika dan siswa tidak hanya aktif dalam berpikir namun dapat merangsang siswa untuk berani menyampaikan pendapatnya serta siswa dapat mempelajari sendiri materi pelajaran dari macromedia flash $8 \mathrm{di}$ rumahnya masing-masing.

\section{Hipotesis Kedua}

Hipotesis kedua, prestasi belajar siswa dilihat dari motivasi belajar matematika siswa. Berdasarkan uji anava dua jalan sel tak sama yang telah dilakukan, diperoleh $\mathrm{F}_{\mathrm{b}}=25,915$ dengan $\mathrm{F}_{\text {tabel }}=3,00$.

Dengan demikian $F_{b}>F_{\text {tabel }}$, sehingga dapat disimpulkan bahwa $H_{O B}$ 
ditolak. Hal ini berarti bahwa terdapat perbedaan prestasi belajar antara motivasi belajar tinggi, sedang, dan rendah terhadap prestasi belajar matematika siswa pada pokok bahasan logaritma.

Berdasarkan uji lanjut pasca anava, diperoleh perhitungan uji komparasi ganda antar kolom dengan $\alpha=0,05$, diperoleh $F_{.1-2}=$ $30,929>F_{\text {tabel }}=6,00$ sehingga $H_{0}$ ditolak. Dengan melihat rataan marginal motivasi belajar tinggi yaitu 84,67 dan rataan marginal motivasi belajar sedang yaitu 75,09, diperoleh kesimpulan bahwa siswa yang memiliki motivasi belajar yang tinggi mempunyai prestasi belajar matematika yang lebih baik daripada siswa yang mempunyai motivasi belajar sedang.

Selanjutnya, pada kolom kedua dan ketiga dengan perhitungan uji komparasi ganda antar kolom diperoleh $\mathrm{F}_{.2-3}=10,446>\mathrm{F}_{\text {tabel }}=$ 6,00 sehingga $H_{0}$ ditolak. Dengan melihat rataan marginal motivasi belajar sedang yaitu 75,09 dan rataan marginal motivasi belajar rendah yaitu 69,25, diperoleh kesimpulan bahwa siswa yang memiliki motivasi belajar sedang mempunyai prestasi belajar matematika yang lebih baik daripada siswa yang mempunyai motivasi belajar yang rendah.

Pada kolom pertama dan ketiga dengan perhitungan uji komparasi ganda antar kolom, diperoleh $F_{.1-3}=52,997>F_{\text {tabel }}=6,00$ sehingga $\mathrm{H}_{0}$ ditolak. Dengan melihat rataan marginal motivasi belajar tinggi yaitu 84,67 dan rataan marginal motivasi belajar rendah yaitu 69,25, diperoleh kesimpulan bahwa siswa yang mempunyai motivasi belajar yang tinggi mempunyai prestasi belajar yang lebih baik daripada siswa yang mempunyai motivasi belajar rendah.

Dengan memperhatikan hasil uji komparasi di atas, dapat diambil kesimpulan bahwa penggunaan media pembelajaran macromedia flash 8 yang sebelumnya belum pernah dilakukan oleh guru, dapat menimbulkan daya tarik tersendiri untuk siswa sehingga siswa termotivasi di dalam belajar matematika. Hal ini telah dibuktikan dimana motivasi belajar siswa yang tinggi akan mendorong aktivitas 
Eksperimentasi Penggunaan Media Komputer dalam Pembelajaran Matematika pada Pokok Bahasan Logaritma Ditinjau dari Motivasi Belajar Siswa Kelas X Sma Kota Surakarta

belajar siswa menjadi lebih baik. Semakin baik motivasi belajar serta aktivitas belajar seseorang maka semakin baik pula prestasi belajar matematikanya.

Dengan demikian, kesimpulannya adalah siswa yang memiliki motivasi belajar yang tinggi akan memiliki prestasi belajar yang lebih baik jika dibandingkan dengan siswa yang memiliki motivasi belajar sedang dan rendah.

\section{Hipotesis Ketiga}

Hipotesis ketiga, prestasi belajar siswa dilihat dari penggunaan media pembelajaran dan motivasi belajar siswa. Berdasarkan uji anava dua jalan sel tak sama yang telah dilakukan, diperoleh $F_{a b}=0,985$ dengan $F_{\text {tabel }}=3,00$. Dengan demikian $F_{a b}<F_{\text {tabel, sehingga dapat }}$ disimpulkan bahwa $\mathrm{H}_{\mathrm{OAB}}$ diterima. Hal ini berarti bahwa tidak terdapat interaksi antara penggunaan media pembelajaran dan motivasi belajar siswa terhadap prestasi belajar siswa pokok bahasan logaritma.

Oleh karena itu, kesimpulan pada efek sederhana mengikuti efek utama yaitu pembelajaran matematika dengan media pembelajaran macromedia flash 8 mempunyai prestasi belajar lebih baik daripada siswa yang diberi pembelajaran dengan menggunakan media pembelajaran powerpoint, baik pada kategori motivasi belajar siswa tinggi, sedang maupun rendah.

Di lain pihak, pada penggunaan media pembelajaran dengan macromedia flash 8 , prestasi belajar siswa dengan motivasi belajar tinggi lebih baik daripada prestasi belajar siswa dengan motivasi belajar sedang dan rendah dan prestasi belajar siswa pada motivasi belajar sedang lebih baik daripada prestasi belajar siswa dengan motivasi belajar rendah.

Demikian pula pada penggunaan media pembelajaran dengan powerpoint, prestasi belajar siswa dengan motivasi belajar tinggi lebih 
Arif Ganda Nugroho

baik daripada prestasi belajar siswa dengan motivasi belajar sedang dan motivasi belajar rendah serta prestasi belajar siswa pada motivasi belajar sedang lebih baik daripada prestasi belajar siswa dengan motivasi belajar rendah.

Dalam proses pembelajaran matematika, penggunaan media pembelajaran merupakan salah satu faktor yang mempengaruhi prestasi belajar siswa, sedangkan motivasi belajar yang dimiliki siswa juga memberikan pengaruh terhadap prestasi belajar siswa tetapi tidak ada interaksi diantara keduanya. Penggunaan media pembelajaran macromedia flash 8 dan media pembelajaran powerpoint memberikan prestasi belajar siswa yang lebih baik. Begitu pula dengan motivasi belajar siswa yang memberikan prestasi belajar yang baik, semakin tinggi motivasi belajar siswa maka semakin baik pula prestasi belajar siswa yang didapat.

\section{Kesimpulan}

Berdasarkan kajian teori dan hasil analisis serta mengacu pada perumusan masalah yang telah diuraikan pada bab-bab sebelumnya, dapat ditarik kesimpulan sebagai berikut:

1. Pembelajaran dengan menggunakan media pembelajaran macromedia flash 8 menghasilkan prestasi belajar matematika yang lebih baik jika dibandingkan dengan menggunakan media pembelajaran powerpoint pada pokok bahasan logaritma siswa Kelas X SMA SSN Kota Surakarta Tahun Pelajaran 2010/2011.

2. Prestasi belajar siswa dengan motivasi belajar tinggi lebih baik daripada prestasi belajar siswa dengan motivasi belajar sedang, prestasi belajar siswa dengan motivasi belajar sedang lebih baik daripada prestasi belajar siswa dengan motivasi belajar rendah, dan prestasi belajar siswa dengan motivasi belajar tinggi lebih baik daripada prestasi belajar siswa dengan motivasi belajar rendah pada pokok bahasan logaritma siswa Kelas X SMA SSN Kota Surakarta Tahun Pelajaran 2010/2011. 
Eksperimentasi Penggunaan Media Komputer dalam Pembelajaran Matematika pada Pokok Bahasan Logaritma Ditinjau dari Motivasi Belajar Siswa Kelas X Sma Kota Surakarta

3. Tidak terdapat interaksi antara media pembelajaran dan motivasi belajar siswa terhadap prestasi belajar siswa. Maksudnya yaitu pembelajaran matematika dengan media pembelajaran macromedia flash 8 mempunyai prestasi belajar lebih baik dari pada siswa yang diberi pembelajaran dengan menggunakan media pembelajaran powerpoint baik pada kategori motivasi belajar siswa tinggi, sedang dan rendah. Di lain pihak pada penggunaan media pembelajaran dengan macromedia flash 8 , prestasi belajar siswa dengan motivasi belajar tinggi lebih baik daripada prestasi belajar siswa dengan motivasi belajar sedang dan rendah dan prestasi belajar siswa pada motivasi belajar sedang lebih baik daripada prestasi belajar siswa dengan motivasi belajar rendah. Demikian pula pada penggunaan media pembelajaran dengan powerpoint, prestasi belajar siswa dengan motivasi belajar tinggi lebih baik daripada prestasi belajar siswa dengan motivasi belajar sedang dan motivasi belajar rendah dan prestasi belajar siswa pada motivasi belajar sedang lebih baik daripada prestasi belajar siswa dengan motivasi belajar rendah pada pokok bahasan logaritma siswa Kelas X SMA SSN Kota Surakarta Tahun Pelajaran 2010/2011.

\section{Daftar Pustaka}

Agus Suntoro. 2009. Eksperimentasi Pembelajaran Matematika Menggunakan Pendekatan Konstruktivistik Dengan Multimedia Komputer Ditinjau Dari Aktivitas Belajar Siswa Kelas VIII SMP N Kota Surakarta Tahun Ajaran 2008/2009. Tesis. Surakarta: Program Pasca Sarjana UNS.

Aida Suraya Md Yunus dan Wan Zah Wan Ali. 2009. Motivation in the Learning of Mathematics. European Journal of Social Science. Volume 7, Number 4, Page: 93-101.

Andi Pramono. 2006. Presentasi Multimedia dengan Macromedia Flash. Yogyakarta: Andi Offset. 
Arif Ganda Nugroho

Arief S Sadiman dkk. 2008. Media Pendidikan Pengertian, Pengembangan, dan Pemanfaatannya. Jakarta: Raja Grafido Persada.

Ariesto Hadi Sutopo. 2002. Animasi dengan Macromedia Flash Berikut Action Script. Jakarta: Salemba Infotek.

Azhar Arsyad. 2007. Media Pembelajaran. Jakarta: PT Raja Grafindo Persada.

Budiyono. 2003. Metodologi Penelitian Pendidikan. Surakarta: UNS Press

Budiyono. 2009. Statistika Untuk Penelitian Edisi Ke-2. Surakarta: UNS Press

Davis, Brent., et al. 2003. Understanding Learning System: Mathematics Education and Complexity Science, Journal for research in Mathematics Education. Volume 34, Number 2, page 137-167.

Departemen Pendidikan dan Kebudayaan. 2005. Kamus Besar Bahasa Indonesia. Jakarta: Balai Pustaka.

Ellington, Aimee J., et al. 2003. A Meta-Analysis of the Effects of Calculators on Students' Achievement and Attitude Levels in Precollege Mathematics Clasess, Journal for Research in Mathematics Education. Volume 34, Number 5, page 433-463.

Goldman, Juliette D. G. et al. 2002. Contructivist Pedagogies Of Interactivity On A CD-ROM To Enhance Academic Learning At A Tertiary Institusion, International Journal of Education Technology. Volume 3, page 155-165.

Hamzah B. Uno. 2007. Teori Motivasi dan Pengukurannya. Jakarta: Bumi Aksara.

Heinnich, Robert. 1996. Instructional and Media Technologies for Learning. New Jersey: Prince Hall.

Jainicki, Thomas N. 2002. Development of a Model for Computer Supported Learning System, International Journal of Education Technology. Volume 3, Number 1, page 127-141.

Klocek, Stefan. 2008. Human Motivation as a Way to Understand User Goals. Cooper Journal.

Lipponen, Lasse. 2002. Exploring Foundations for Computer-Supported Collaborative Learning, International Journal of Education Technology. Volume 3, page 155-165 
Eksperimentasi Penggunaan Media Komputer dalam Pembelajaran Matematika pada Pokok Bahasan Logaritma Ditinjau dari Motivasi Belajar Siswa Kelas X Sma Kota Surakarta

Mr. I Malabar \& D. C. Pountney. 2002. Using Technology To Integrate Constructivism And Visualisation In Mathematics Educations. Journal Research of Mathematics Education. Volume 27, Number 2 , Page 133-150.

Mulyono Abdurrahman. 1999. Pendidikan Bagi Anak Berkesulitan Belajar. Jakarta: Rineka Cipta.

Nana Syaodih Sukmadinata. 2007. Metode Penelitian Pendidikan. Bandung: Remaja Rosdakarya.

Oleksiy Yevdokimov. About A Constructivist Approach For Stimulating Students' thinking To Produce Conjectures and Their Proving in Active Learning of Geometry, Karkov State Pedagogical University.

Risma Jayanti. 2007. Perancangan Media Pembelajaran Matematika Berbasis Teknologi Informasi dan Komunikasi (TIK) Di Sekolah Menengah Atas Pada Pokok Bahasan Logaritma. Skripsi, UMS Tidak Diterbitkan.

Saxena, Anshu., et al. 2004. Analyzing Hypermedia and Internet Communication Models in Educational Applications, Internasional Journal of Education Technology. Volume 12, Number 1, page 111120.

Sardiman. 2002. Interaksi dan Motivasi Belajar Mengajar. Jakarta: Raja Grafindo Persada.

Slametto. 2003. Belajar dan Faktor-faktor yang Mempengaruhinya. Jakarta: PT Rineka Cipta.

Suharsimi Arikunto. 2001. Dasar-dasar Evaluasi Pendidikan. Jakarta: Bumi Aksara.

Suharsimi Arikunto. 2005. Prosedur Penelitian : Suatu Pendekatan Praktek. Jakarta: Rineka Cipta.

Sudjana dan Rivai. 2001. Media Pengajaran. Jakarta: Sinar Baru Algesindo.

Winkel, WS. 1996. Psikologi Pengajaran. Jakarta: Gramedia Widiasarana.

Yahya Kurniawan. 2006. Belajar Sendiri Macromedia Flash 8. Jakarta: PT Elex Media Komputindo.

\section{Arif Ganda Nugroho}

IAIN Antasari, Banjarmasin

E-mail: 